\title{
Glucocorticoids in the treatment of neonatal meconium aspiration syndrome
}

\author{
Daniela Mokra • Juraj Mokry
}

Received: 13 October 2010 /Accepted: 14 March 2011 /Published online: 6 April 2011

(C) The Author(s) 2011. This article is published with open access at Springerlink.com

\begin{abstract}
Meconium aspiration syndrome is a serious neonatal disease with complex pathophysiology. With respect to the contribution of meconium-induced lung edema, inflammation and vasoconstriction on the course of the disease, glucocorticoids are increasingly used in the treatment of MAS despite the fact that principal questions on the choice of GCs derivative, mode of delivery and dosing have not been answered yet. To bring a complex insight into the topic, this article reviews the pathomechanisms of MAS, mechanisms of action of GCs, as well as the advantages and disadvantages of GCs administration in experimental models and newborns with MAS.
\end{abstract}

Keywords Meconium aspiration · Glucocorticoids . Inflammation

\section{Introduction}

Meconium aspiration syndrome

Meconium aspiration syndrome (MAS) is a major cause of respiratory morbidity and mortality in the term and postterm newborns. The incidence of MAS in the welldeveloped countries stands at about one to two per 1,000

D. Mokra $(\bowtie)$

Department of Physiology, Jessenius Faculty of Medicine,

Comenius University,

Mala Hora 4, SK-03601,

Martin, Slovakia

e-mail: mokra@jfmed.uniba.sk

J. Mokry

Department of Pharmacology, Jessenius Faculty of Medicine, Comenius University,

Martin, Slovakia live births; however, in the developing countries, this number may be considerably higher [19]. The clinical picture varies from mild tachypnoea to life-threatening respiratory failure associated with pulmonary hypertension [16]. In addition to acute effects, MAS may also have serious long-term consequences on the respiratory system, whereas abnormal bronchial reactivity, wheezing and other respiratory pathology were found in a considerable portion of infants who overcome MAS in the neonatal period [80].

Despite an improved understanding of the pathomechanisms of MAS and widening the available therapeutic approach, MAS is often difficult to treat. Therefore, a number of various adjunctive or alternative approaches have been tested in MAS. Since some of them have been rather well established (e.g. different modes of ventilatory support, surfactant treatment and inhaled nitric oxide), the therapeutic potential of others (particularly of anti-inflammatory drugs and vasodilators) is still under research [48].

Pathogenesis of MAS as a rationale for the treatment by glucocorticoids

The pathogenesis of MAS is complex, with multiple interactions between the individual pathomechanisms [48]. In an acute phase of the disease, aspirated meconium obstructs the airways. Complete airway obstruction may result in alveolar atelectasis behind the plug. Partial airway obstruction may cause a ball valve effect, and air trapping and air leak into the interstitium may occur [16].

With the initiation of ventilation, aspirated meconium reaches the alveoli, where it inactivates the surfactant [56] and triggers inflammation [86]. Meconium changes the viscosity and ultrastructure of the surfactant [2], decreases the levels of surfactant proteins [15] and accelerates the conversion from large, surface active aggregates into small, less active 
forms [35]. Both fractions of meconium, water-soluble (containing bilirubin, bile acids, enzymes, etc.) and lipidsoluble (containing free fatty acids, cholesterol, triglycerides, etc.) ones, impair lung functions [56]; however, the lipidsoluble fraction is much more deleterious [76]. The dysfunction of surfactant is further potentiated by plasma proteins leaking through an injured alveolocapillary membrane, as well as by the action of proteolytic enzymes and reactive oxygen and nitrogen species (RONS) released from activated cells during the inflammation.

Meconium itself acts as a potent chemoattractant for neutrophils [87], increasing their number in the lungs within several hours after the aspiration, which is linked with their decrease in the blood $[55,66]$. In addition, meconium is a source of pro-inflammatory mediators, such as interleukins (IL) $-1,-6$ and -8 , tumour necrosis factor $\alpha(\mathrm{TNF} \alpha)$, etc. [20]; thus, it may induce inflammation directly or indirectly through the stimulation of oxidative burst in neutrophils [69] and alveolar macrophages [17]. The activated macrophages and released cytokines may stimulate the adhesion of neutrophils on the endothelium and the formation of microemboli in the capillary bed, participating in the onset of pulmonary hypertension. This process is facilitated by complement, the activation of which has been proved also in MAS [11]. The activated cells (leukocytes, platelets, epithelial and endothelial cells, etc.) produce a wide spectrum of substances like TNF $\alpha$, IL, leukotrienes (LT), prostaglandins (PG), platelet-activating factor (PAF), proteolytic enzymes and RONS, injuring the lung parenchyma and surfactant [27, 92]. Inflammatory cytokines induce angiotensin II (ANG II) expression which, after binding to AT1 receptors, cause apoptotic death of the lung cells as well [82]. Subsequently, a leak of proteinaceous fluid and cells into the alveolar spaces through the alveolocapillary membrane further deteriorates the lung function. In addition, meconium contains high concentrations of phospholipase $\mathrm{A}_{2}\left(\mathrm{PLA}_{2}\right)$, which may directly or via the arachidonic acid metabolism increase the production of lipid mediators and participate in the apoptosis of epithelial cells [29] and surfactant dysfunction [65]. Meconium also enhances the expression of inducible cyclooxygenase-2 (COX-2) and inducible nitric oxide synthase (iNOS) in the macrophages and epithelial and endothelial cells [42, 44]. Furthermore, the release of bronchoactive substances like LT and PAF is probably responsible for increased airway reactivity to bronchoconstrictor agents $[38,55]$.

Meconium aspiration is often associated with pulmonary vasoconstriction from hypoxia and/or from the vasoconstriction effect of meconium and substances released during the inflammation. The presence of meconium in the amniotic fluid may cause ischemic changes of the lungs, umbilical cord and placenta [7]. Postnatal meconium instillation elevates the pulmonary artery pressure and vascular resistance in a concentration-dependent manner
[28], which is linked with higher levels of thromboxane $A_{2}$ (TXA $)$ ), LT, PG and endothelin-1 (ET-1) $[41,68,86]$.

\section{Glucocorticoids}

Mechanisms of action

Cortisol, a major endogenous glucocorticoid (GC), is secreted by the cortex of adrenal glands. Only a small proportion of GCs $(<10 \%)$ is free and metabolically active since majority of GCs is bound to proteins during their transport in the blood. The daily production of cortisol in adults may be about 13$20 \mathrm{mg}$ and may increase up to $300 \mathrm{mg} /$ day [75]. In children and adolescents, the daily production of cortisol is about $6.8 \mathrm{mg} / \mathrm{m}^{2} /$ day [45]. The plasma concentration of cortisol in adults varies in the range of $50-500 \mathrm{nmol} / \mathrm{l}$, in the term newborns about $140 \mathrm{nmol} / 1$ and in premature newborns about $180 \mathrm{nmol} / \mathrm{l}$ [75]. The action of GCs contributes to the compensatory mechanisms which help the body to get a stress situation under control. GCs supply energy for these processes by protein catabolism, gluconeogenesis and glucogenesis, finally resulting in hyperglycaemia, hyperlipidemia and other changes in the blood, bones, muscles and cardiovascular, gastrointestinal, endocrinal and central nervous systems [24, 34].

Free GC molecules penetrate through the cell membrane into the cytoplasm, where they interact with a specific glucocorticoid receptor (GR). Heat-shock protein HSP90, which is normally attached to a free GR and prevents its transport to the nucleus, is released in this process. After binding GCs to a GR receptor, the activated complex moves into the nucleus and binds to a specific nuclear sequence of DNA (glucocorticoid-responsive element, GRE). As a result, it may activate or inhibit the transcription of mRNA and thereby modulate the production of various proteins (Figs. 1 and 2). The newly synthesized substances then mediate physiological or pharmacological responses, including metabolic and anti-inflammatory effects.

In case of their anti-inflammatory action, the activated GR complex interacts with negative-responsive element (GRE ${ }^{-}$). The subsequent inhibition of transcription factors including nuclear factor (NF)- $\mathrm{KB}$ and protein activator (AP)-1 inhibits the expression of pro-inflammatory cytokines (IL-1, IL-6, IL-8, TNF $\alpha$, etc.), enzymes (PLA 2 , COX-2, iNOS, etc.) and other biologically active substances such as PAF, ET-1, ICAM-1, etc. [24, 34, 57] (Fig. 2).

The anti-inflammatory effect of GCs is supplied also through enhancing the activity of lipocortines. The increased transcription of lipocortine-1 in leukocytes is related to the interaction of GC-GR complex to the positive-responsive element of DNA $\left(\mathrm{GRE}^{+}\right)$. Lipocortines inhibit the activity of $\mathrm{PLA}_{2}$ and thereby decrease the 
Fig. 1 Genomic and nongenomic action of glucocorticoids. $G C$, glucocorticoid; $c G R$, cytoplasmic GC receptor; $m G R$, membranebound GC receptor; HSP90, heat shock protein 90; Src, protein. For explanation, please see the text. (Adapted by Buttgereit et al. [10] and Stahn et al. [70])

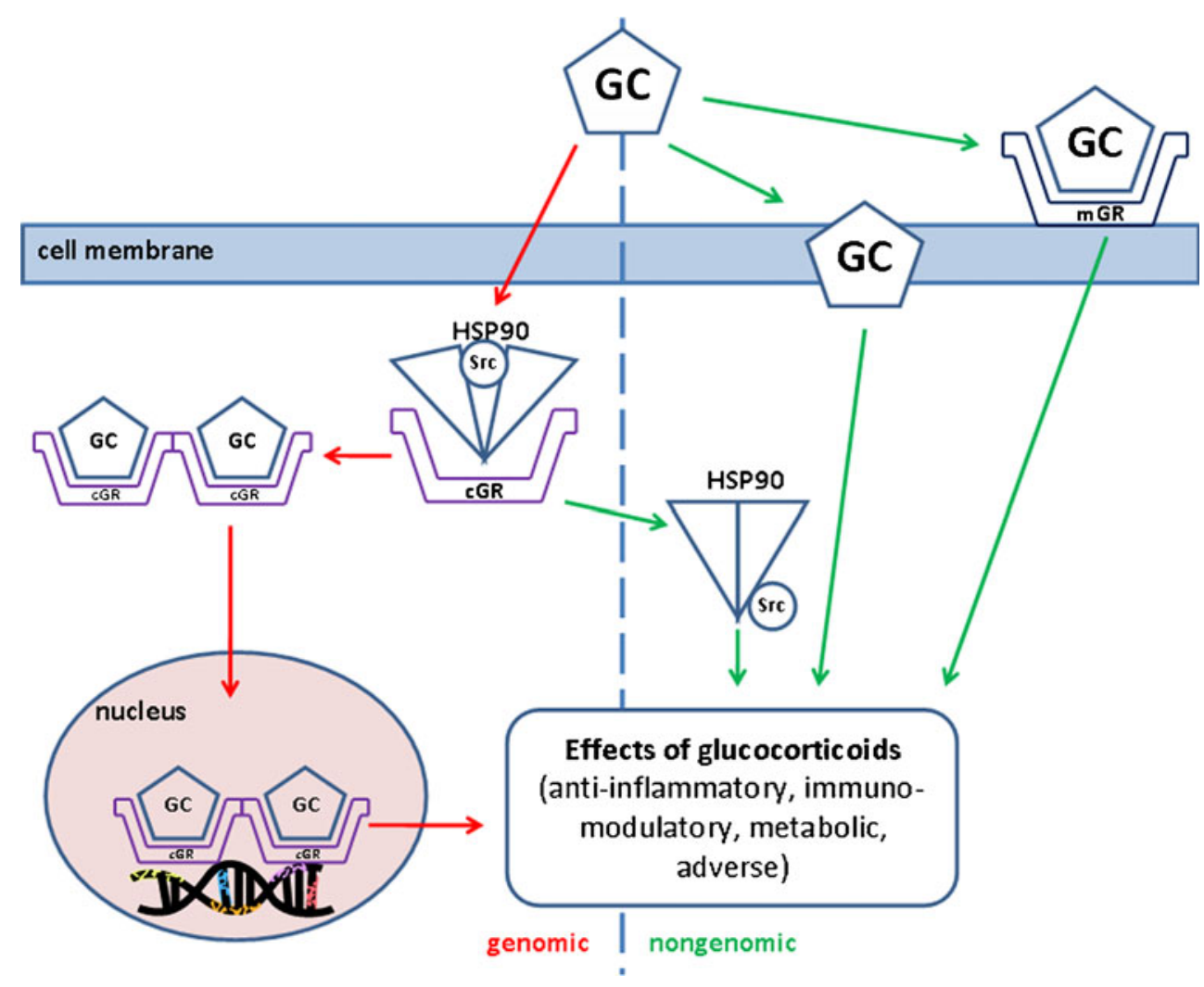

production of arachidonic acid and mediators of lipooxygenase and cyclooxygenase pathway as well as of PAF [57]. It is assumed that the activation of the cell by a noxious stimulus causes the inactivation of lipocortines and development of inflammation. On the contrary, the increased production of lipocortines induced by GCs has opposite, anti-inflammatory effects [57].

GCs reduce the penetration of neutrophils into the lungs, decreasing their adherence to the endothelium and thereby increasing secondarily a count of circulating neutrophils [30, 50, 51, 55, 66]. Moreover, GCs decrease the counts of circulating mononuclears, eosinophils and basophils as well as the synthesis of cytokines by macrophages, eosinophils and T lymphocytes. GCs stabilize lysosomes, inhibit the release of lysosomal enzymes, chemotaxia and other functions of neutrophils as well [34]. Furthermore, GCs stimulate the production of secretion leukocyte protease inhibitor, an important antiprotease, which may suppress an inflammation in the airways. GCs facilitate the transcription of $\beta_{2}$-receptor gene and reduce the mast cells count and production of mucus in the airways, too. By stabilizing the cell membranes and decreasing the production of proinflammatory and vasoactive substances, GCs reduce microvascular permeability. In addition, by direct modulation of the pulmonary vasomotoric tone, GCs diminish pulmonary vasoconstriction and inhibit fibrogenesis [24, 34].
Fig. 2 Trans-activation or transrepression of gene caused by $\mathrm{GC}-\mathrm{GR}$ binding in cell nucleus. $G C$, glucocorticoid; $c G R$, cytoplasmic GC receptor; $G R E^{+}$, positive glucocorticoid responsive element; GRE , negative glucocorticoid responsive element; $I L$, interleukin; $A P-1$, protein activator-1; $N F \kappa B$, nuclear factor $\mathrm{\kappa B}$; IRF3, interferon regulatory factor 3 . For explanation, please see the text

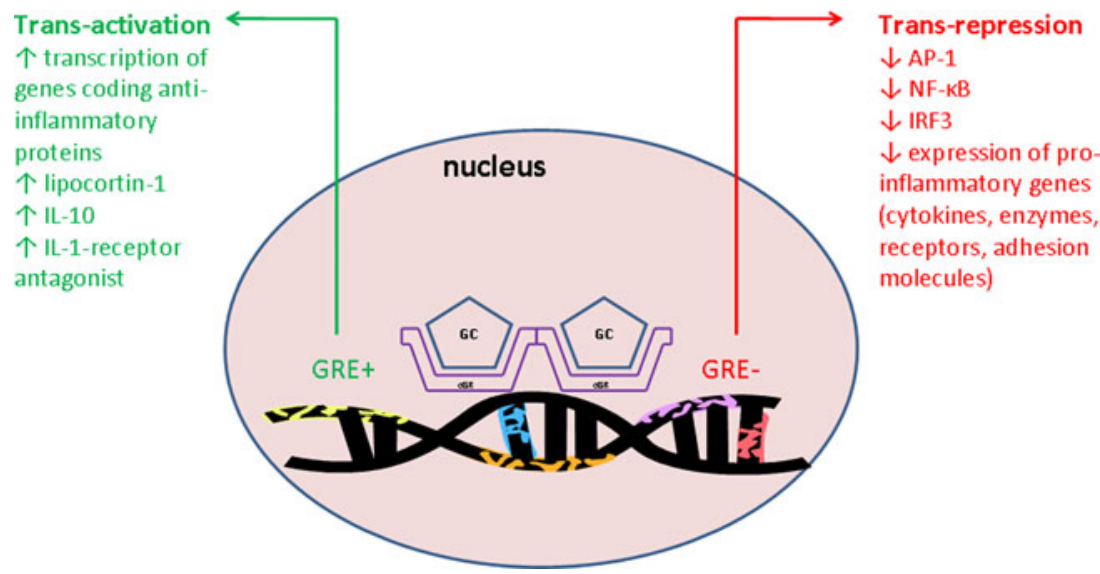


Majority of the above-mentioned action of GCs is mediated by interactions with intracellular cytoplasmic receptors, leading to the production of protein with specific regulatory functions. In these genomically mediated processes, transcription and translation with subsequent proteosynthesis requires at least several hours until some changes may be observed on the systemic level. However, GCs act also through nongenomically mediated mechanisms, which are responsible for rapid GCs action until the effects mediated by genomic mechanisms occur [71]. In literature, three possible nongenomic mechanisms are discussed (Fig. 1): specific interaction with cytosolic GC receptors (cGCR) and successive release of HSP90 and special proteins Src and MAPK, non-specific interactions with cellular membranes and specific interactions with membrane-bound glucocorticoid receptors. GCs may exert rapid effects on various tissues and cells, modulating hormone secretion, neuronal excitability, carbohydrate metabolism, cell morphology, cell behaviour and other processes within seconds or minutes [23, 71]. The GC action may be related to affecting ion cycling [81], cellular energy metabolism [8] or neuronal activity [12], as well as to rapid effects on second messenger systems [8]. In the respiratory system, GCs presumably via nongenomic action modulated $\mathrm{Na}^{+} / \mathrm{H}^{+}$exchange activity in bronchial epithelial cells [81] and inhibited airway smooth muscle contraction within 10 min after GCs inhalation [73, 91]. Similarly, in a rabbit model of MAS, GCs already significantly improved several respiratory parameters within $30 \mathrm{~min}$ after the administration [50, 51].

In addition, interactions between genomic and nongenomic mechanisms have been claimed, thereby controlling genomic mechanisms through nongenomic ones [85]. Nongenomic effects occur faster and may be clinically relevant over a limited period, "bridging the gap" until the long-term genomic effects take place [9].

Irrespective of the mechanisms of their action, GCs may effectively suppress polymorphonuclear inflammation, lung edema formation and pulmonary vasoconstriction. However, the effect of the treatment depends on the specific properties, dose and mode of delivery of the individual GCs as well as on the current status of the newborn or experimental animal with MAS.

\section{Glucocorticoids in the treatment of MAS}

Despite GCs having been used in various animal models of MAS as well as in several clinical studies, some questions still remain unanswered. Particularly:

1. According to the pharmacological properties, which of the available synthetic GC preparations is the best choice-i.e. most effective with low side effects?
2. What way of GCs administration is better-intravenous or intratracheal?

3. What dosing and timing should be used? When to administer GCs and in what dose per individual GCs preparation? Is it better to use single or repetitive doses of the GC preparative?

4. Is it possible to combine GCs with other drugs emphasizing their favourable effects?

\section{Pharmacological properties of GCs preparations}

Individual GCs may exert different pharmacological properties including different mineralocorticoid activity. Although accepted in practice, the clinical potencies of GC preparations have been difficult to assess using classical approaches. For example, the potency of GCs to suppress cortisol production does not sufficiently reflect the ability to suppress inflammation [21]. In addition, it is suggested that different GCs may have different potency per target tissue. The basic characteristics of commonly prescribed GCs preparations are listed in Table 1.

In addition, regarding their nongenomic action, the relative drug potency of individual GCs may differ from the hierarchy for the classic genomic effects. For example, assessing some rapid nongenomic effects, dexamethasone was shown to be the most potent among the tested GCs, thanks probably to the lowest lipophilicity facilitating its interaction directly with the cell membrane $[9,46,64,79]$.

\section{Side effects of GCs}

The administration of GCs may be accompanied by mostly unwanted side effects due to their influencing the physiological processes in the body. The occurrence and intensity of adverse effects depend on the type of GCs preparation, dosing, timing and way of administration. While adverse effects are rare in the administration of low ("physiological" or "substitutional") doses of GCs in substitution therapy, the long-term administration of high ("pharmacological" or "supraphysiological") doses of GCs may be associated with the side effects of various characters. GC drugs suppress the function of the hypothalamic-pituitary-adrenal axis, decreasing the secretion of corticotropin, which in turn reduces the secretion of cortisol by adrenal glands. Prolonged adrenal suppression may cause reduced responses to stress [3]. In addition, long-term GCs administration may lead to hyperglycaemia, hypokalemia, dyslipidemia, reduced fibrinolysis, hypertension, posterior subcapsular cataract, exacerbation of glaucoma, increased intracranial pressure, peptic ulcers, upper gastrointestinal bleeding, immunosuppression, neuropsychiatric disturbances, osteoporosis, myopathy, irregularities of the menstruation cycle, etc. [63]. 
Table 1 Basic characteristics of commonly used natural and synthetic corticosteroids [36]

\begin{tabular}{|c|c|c|c|c|c|c|}
\hline \multirow[t]{2}{*}{ Agent } & \multicolumn{4}{|c|}{ Activity } & \multirow{2}{*}{$\begin{array}{l}\text { Equivalent oral } \\
\text { dose (mg) }\end{array}$} & \multirow{2}{*}{$\begin{array}{l}\text { Forms } \\
\text { available }\end{array}$} \\
\hline & Anti-i & nflammatory & Topical & Salt-retaining & & \\
\hline \multicolumn{7}{|l|}{ Short- to medium-acting GCs } \\
\hline Hydrocortisone (cortisol) & & 1 & 1 & 1 & 20 & p.o., inj., top. \\
\hline Cortisone & & 0.8 & 0 & 0.8 & 25 & p.o. \\
\hline Prednisone & & 4 & 0 & 0.3 & 5 & p.o., inj. \\
\hline Prednisolone & & 5 & 4 & 0.3 & 5 & p.o., inj. \\
\hline Methylprednisolone & & 5 & 5 & 0 & 4 & p.o., inj. \\
\hline Meprednisone & & 5 & - & 0 & 4 & p.o., inj. \\
\hline \multicolumn{7}{|l|}{ Intermediate-acting GCs } \\
\hline Triamcinolone & 5 & & 5 & 0 & 4 & p.o., inj., top. \\
\hline Paramethasone & 10 & & - & 0 & 2 & p.o., inj. \\
\hline Fluprednisolone & 15 & & 7 & 0 & 1.5 & p.o. \\
\hline \multicolumn{7}{|l|}{ Long-acting GCs } \\
\hline Betamethasone & $25-40$ & & 10 & 0 & 0.6 & p.o., inj., top. \\
\hline Dexamethasone & 30 & & 10 & 0 & 0.75 & p.o., inj., top. \\
\hline \multicolumn{7}{|l|}{ Mineralocorticoids } \\
\hline Fludrocortisone & 10 & & 0 & 250 & 2 & p.o. \\
\hline Desoxycorticosterone acetate & 0 & & 0 & 20 & - & p.o., inj. \\
\hline
\end{tabular}

Due to the relatively wide spectrum and high risk of side effects of systemic GCs, the local administration of GCs is generally preferred. However, depending on the system of delivery and dose used, $<20 \%$ of the nebulized GCs is deposited into the lungs and the rest may be absorbed into the circulation from the gastrointestinal system and subsequently cause systemic effects [61]. In addition, inhalation of GCs may worsen the course of bacterial infections after initial improvement and may increase the risk of oropharyngeal candidiasis, dysphonia, cough, throat irritation and other local side effects [3].

\section{Use of GCs in perinatal respiratory diseases}

In respirology, GCs (mainly inhalational GCs such as budesonide) are used in asthma and exacerbations of chronic obstructive pulmonary disease [6, 43, 61]. In perinatal period, GCs may be administered antenatally or postnatally. Antenatal GCs (particularly betamethasone and dexamethasone) are used to induce early lung maturation and stimulate the synthesis of pulmonary surfactant in premature infants [5, 60]. Postnatally, GCs (especially dexamethasone) take part in the treatment of chronic lung disease or bronchopulmonary dysplasia after neonatal respiratory distress syndrome [1, 40, 83]. However, longterm GCs administration may exert adverse effects on neuromotor function and the somatic growth of the treated infants [89]. In adult/acute respiratory distress syndrome, GCs (mostly methylprednisolone) may be of benefit in fibroproliferative or late phase of the disease, but use in the early stages of the disease is controversial [24, 34].

\section{Use of GCs in MAS}

In animal models and in newborns with MAS, hydrocortisone, prednisolone, methylprednisolone, dexamethasone and budesonide have been used, with the subjects having various responses to treatment.

Hydrocortisone is a synthetic equivalent of cortisol and used as an immunosuppressive drug in severe allergic reactions such as anaphylaxis and angioedema. Comparing the strength for the anti-inflammatory effect, prednisolone is about four times and dexamethasone is about 30 times stronger than hydrocortisone. Thanks to both glucocorticoid and mineralocorticoid effects, hydrocortisone may be used in substitution therapy; however, expressing mineralocorticoid activity, hydrocortisone may potentiate a dysbalance of liquids and electrolytes in the body.

In the study by Frantz et al. [25] carried out in 1975, the subcutaneous administration of hydrocortisone at a dose of $7.5 \mathrm{mg} / \mathrm{kg}$ immediately after meconium instillation and then every $8 \mathrm{~h}$ up to $48 \mathrm{~h}$ non-significantly improved the histology of the lungs and decreased the frequency of breathing in newborn rabbits. However, a higher mortality of the hydrocortisone-treated animals was observed irrespective if they aspired meconium or saline, probably due to the infection at the tracheotomy site and sepsis [25]. Two years later, hydrocortisone, at a dose of $20 \mathrm{mg} / \mathrm{kg}$, was 
administered four times every $12 \mathrm{~h}$ via umbilical catheter in 17 neonates with MAS [88]. Blood gases, X-ray, incidence of pneumothorax or pneumomediastinum, requirements for mechanical ventilation and mortality were comparable in the hydrocortisone-treated vs. placebo-administered group. However, longer period to wean to room air and remaining clinical signs of respiratory distress were observed in the treated group than in controls [88]. We may speculate that no benefit of the treatment may be caused by low dose or by late treatment, respectively, since the first dose of hydrocortisone was administered at about $5 \mathrm{~h}$ of age [88] when severe respiratory distress and inflammation have already been developed. No effect of hydrocortisone on meconium-induced lung edema in the study by Frantz et al. [25] may be explained by fluid retention in the lungs or delayed reabsorption of the fluid due to mineralocorticoid action of hydrocortisone. In addition, the anti-inflammatory potential of hydrocortisone is several times weaker than that of other GCs.

Prednisolone is a GC drug with predominant glucocorticoid and low mineralocorticoid activity. Thanks to its strong anti-inflammatory and immunosuppressive action, it is used for the treatment of a wide range of inflammatory and auto-immune disorders, such as bronchial asthma, rheumatoid arthritis, ulcerative colitis, etc.

In the study by Kirimi et al. [39], the intravenous administration of prednisolone at standard $(2 \mathrm{mg} / \mathrm{kg})$ and high $(30 \mathrm{mg} / \mathrm{kg})$ doses immediately after meconium instillation improved gas exchange and increased the frequency of breathing in meconium-instilled puppies in comparison with the non-treated group. In addition, highdose prednisolone showed a more obvious improvement in lung histology compared to the standard dose, without hyperglycaemia or hypertension as side effects. However, high-dose prednisolone significantly increased the plasma levels of malonyldialdehyde, product of lipid peroxidation, compared to standard-dose group and controls at $20 \mathrm{~h}$ after meconium aspiration. It may suggest a paradoxically lower effectivity of high-dose vs. standard-dose prednisolone in the reduction of oxidation stress resulting from inflammation or even the potentiation of oxidation stress by a megadose of prednisolone [39]. Nevertheless, the value of this information is limited by the small number of animals included in the treated groups ( $n=3$ each).

Methylprednisolone, a methylated derivative of prednisolone, has similar properties and use as prednisolone. Since it may reach higher concentrations in the lungs than prednisolone due to a higher distribution volume, slower elimination and higher accumulation in the alveolar epithelium, it is used also for the short-term treatment of bronchial inflammation or acute bronchitis.

Soukka et al. [66] found that, in 10-week-old pigs with MAS, pretreatment with methylprednisolone $(30 \mathrm{mg} / \mathrm{kg}$, i. v.) $30 \mathrm{~min}$ before the instillation of meconium tended to prevent an early $(0-1 \mathrm{~h})$ increase in pulmonary artery pressure and significantly inhibited the second-phase (1$6 \mathrm{~h}$ ) progressive rise in pulmonary artery pressure and pulmonary vascular resistance, decreased venous admixture and formation of lung edema and improved oxygenation [66]. In another study by Soukka et al. [67], premedication with methylprednisolone decreased the level of endothelin (ET)-1 and increased the level of atrial natriuretic peptide (ANP). The modulation of the ratio ET-1/ANP for ANP diminished pulmonary hypertension and indicated the protective effect of GCs on the endothelium-mediated regulation of the pulmonary vascular tone [67]. Thus, premedication with GCs before the labour might be beneficial in the case of verified massive meconium staining of the amniotic fluid and prenatal meconium aspiration to reduce remodelling of the pulmonary vascular lining and lung inflammation. However, up to this time, no clinical study was performed to evaluate the possible benefits of prenatal GCs delivery in MAS.

Postnatally, methylprednisolone has been recently used in two trials carried out in India $[4,77,78]$. Methylprednisolone administered for a period of 7 days starting after $24 \mathrm{~h}$ of age in 34 newborns with MAS shortened the period of oxygen delivery and duration of hospital stay and improved the radiological clearance of the lungs, while no serious adverse effects including sepsis were observed [4]. In the study by Tripathi and co-workers [77, 78], methylprednisolone was given in 17 newborns with MAS at a dose of $0.5 \mathrm{mg} / \mathrm{kg} /$ day, i.v., in two divided doses every $12 \mathrm{~h}$ for 7 days. Similarly to the study by Basu et al. [4], methylprednisolone shortened the duration of stay, oxygen dependence and X-ray of the lungs, decreased the levels of $\mathrm{TNF} \alpha$ in tracheal aspirate and did not increase the incidence of sepsis.

Dexamethasone is a synthetic GC with potent antiinflammatory and immunosuppressive action. It is $>30$ times stronger than hydrocortisone and about five times stronger than prednisone. Dexamethasone is also used for diagnostic procedures (to suppress the natural pituitaryadrenal axis) in obstetrics to promote the maturation of foetal lungs as well as in a wide spectrum of endocrine, oncological and other diseases.

The first successful use of dexamethasone in MAS has been referred to in the 1990s, when it improved pulmonary ventilation and facilitated weaning from the ventilator in several newborns with severe MAS [86]. Later, numerous experimental and clinical studies evaluated the efficacy and management of dexamethasone administration in the conditions of MAS. Commonly, dexamethasone at a dose of $0.5 \mathrm{mg} / \mathrm{kg}$ body weight has been used.

However, the timing of dexamethasone delivery appears to be critical for the effectiveness of treatment. In 
meconium-instilled piglets, pretreatment with dexamethasone ( $1 \mathrm{~h}$ before meconium instillation) reduced pulmonary vascular resistance and lung edema, improved oxygenation and prevented ultrastructural changes of the lungs [30]. Similarly, the early administration of dexamethasone (30 min after meconium instillation) significantly reduced right-to-left pulmonary shunting, improved gas exchange and decreased ventilatory pressures in meconium-instilled rabbits compared to non-treated controls [50]. Furthermore, early dexamethasone decreased the neutrophil count in BAL fluid and reduced lung edema, meconium-induced tracheal hyperreactivity to histamine and concentrations of lipid and protein peroxidation products in the lung homogenate compared to controls $[50,55]$. On the other side, the late administration of dexamethasone $(1 \mathrm{~h}$ after meconium instillation) led to only non-significant improvement of oxygenation and had no effect on lung edema in piglets with MAS [30]. The results have clearly showed a better effect of GCs in early administration occurring before extensive tissue response to the meconium instillation.

Considering time-related inflammatory changes in MAS, limitations of the treatment efficacy in late administration of GCs may be reduced by repetitive administration. It is known that the action of dexamethasone is fast, but of a short term. The half-life of dexamethasone in adults is 110 $190 \mathrm{~min}$, with the biological half-life of 36-72 h [14, 74]. In newborns, the plasma half-life of dexamethasone is 150 $300 \mathrm{~min}$ and the biological half-life is between $36-54 \mathrm{~h}$ [47]. Therefore, in acute situations, repetitive administration every $2-4 \mathrm{~h}$ is recommended (data given by the producer, Dexamed, Medochemie, Cyprus).

In meconium-instilled piglets, two-phase dexamethasone administration at 2 and $8 \mathrm{~h}$ after meconium instillation significantly improved gas exchange and lung compliance compared to controls [37]. In a rabbit model of MAS, the repetitive administration of dexamethasone 0.5 and $2.5 \mathrm{~h}$ after meconium instillation suppressed inflammation and enhanced gas exchange more effectively than a single dose administered $0.5 \mathrm{~h}$ after meconium [50, 52]. Similarly, in newborns with MAS, dexamethasone administered in gradually decreasing doses within maximally 9 days (at a dose of $0.5,0.25$ and $0.125 \mathrm{mg} / \mathrm{kg} /$ day, each administered for 3 days) decreased the oxygenation index and facilitated weaning from the ventilator [18].

Nevertheless, high doses of systemic GCs or their repetitive administration may exert various undesirable effects. Although the acute cardiovascular changes may be critical for neonates with meconium-induced lung injury, the side effects of repetitive GCs administration in MAS have not been investigated yet in a clinical study. In a rabbit model of MAS, the slow intravenous administration of one dose, but especially of two doses of dexamethasone, was associated with acute changes of blood pressure, heart rate and heart rate variability within $5 \mathrm{~h}$ of treatment [52, 54]. A detailed analysis of cardiovascular changes showed increased blood pressure, decreased heart rate, increased heart rate variability and a higher occurrence of cardiac arrhythmias particularly during and immediately after dexamethasone administration, while decreased heart rate and increased heart rate variability were observed until the end of the observation period (i.e. $5 \mathrm{~h}$ after the first dose of dexamethasone) [52, 54].

Budesonide is an inhalational GC used in the treatment of bronchial asthma, non-infectious rhinitis (including hay fever and other allergies) and nasal polyposis. Budesonide has high first-pass metabolism and its administration is associated with a lower incidence of systemic manifestations than with other GCs (fewer bone density losses and little influence on the hypothalamic-pituitary-adrenal axis) [3, 31].

In meconium-instilled rabbits, budesonide (Pulmicort, $0.25 \mathrm{mg} / \mathrm{kg}$ ) was administered intratracheally $30 \mathrm{~min}$ after meconium instillation and then $2 \mathrm{~h}$ later using the inpulsion effect of high-frequency jet ventilation (inspiration time $20 \%$ ). The treatment effectively alleviated inflammation, decreased lung edema formation and meconium-induced tracheal and lung smooth muscle hyperreactivity to histamine, improved gas exchange and decreased the oxidation injury of the lungs compared to non-treated controls [51]. In addition, intratracheal budesonide administration was associated with negligible acute cardiovascular effects [49] compared to dexamethasone $[52,54]$.

In 32 newborns with MAS, budesonide administered for a period of 7 days starting after $24 \mathrm{~h}$ of age shortened the period of oxygen delivery and duration of hospital stay and improved the radiological clearance of the lungs, while no serious adverse effects were found [4]. In another study [77, 78 ], budesonide was given in 17 newborns with MAS at a dose of $50 \mu \mathrm{g} / \mathrm{kg} /$ day, i.v., in two divided doses every $12 \mathrm{~h}$ for 7 days. Comparably to Basu et al. [4], budesonide shortened the duration of stay, oxygen dependence and $\mathrm{X}$ ray of the lungs, decreased the levels of TNF $\alpha$ in tracheal aspirate and did not increase the incidence of sepsis.

Local administration predisposes the inhalational GCs to be faster and of more potent action at the site of inflammation. Thanks to high lipophility, inhalational GCs (budesonide) have rapid direct effects on cells involved in airway inflammation including macrophages, eosinophils, $\mathrm{T}$ lymphocytes and airway epithelial cells [3]. In in vitro comparison of potency to reduce a release of IL-8 from airway epithelial cells, budesonide has shown ten-timesstronger activity than dexamethasone [59]. It corresponds well with our findings in the rabbit model of MAS, where intratracheal budesonide improved gas exchange and reduced lipid and protein peroxidation in the lung tissue more effectively compared to dexamethasone. In addition, budesonide reduced both tracheal and lung smooth muscle hyperresponsiveness to histamine, while dexamethasone 
decreased only tracheal reactivity with no effect on lung tissue [50, 51]. Nevertheless, in the above-mentioned clinical studies [4, 77, 78], no differences between the methylprednisolone- and budesonide-treated groups were found. Similarly, inhaled GCs (beclomethasone) showed no priority to intravenous GCs (dexamethasone) in ventilatordependent preterm newborns [72].

We may speculate that the absence of superior action of locally administered GCs to systemic GCs may be related to the method of administration used - nebulization. Considering high extrapulmonal losses $(>80 \%)$ of nebulized material [61], other ways of administration, such as slow administration directly into the trachea, should be considered. In our study, budesonide administered via inpulsion effect of HFJV effectively improved the lung functions with minimum losses of the drug and negligible side effects [49, 51]. Intratracheal administration of GCs may be further mitigated by the use of suitable vehicle, e.g. saline or exogenous surfactant [22]. In experimental conditions, an addition of GCs to exogenous surfactant did not alter the surface properties of the surfactant and GCs were well distributed throughout the lungs with $30-60 \%$ of the delivered material detected in the lung tissue [58]. In preterm infants, intratracheal instillation of a mixture of budesonide $(0.25 \mathrm{mg} / \mathrm{kg})$ and beractant $(100 \mathrm{mg} / \mathrm{kg})$ every $8 \mathrm{~h}$ decreased the mean airway pressure, oxygenation index and $\mathrm{PCO}_{2}$ and reduced deaths and chronic lung disease at 36th week of postconceptional age compared to the group treated solely by Survanta $(100 \mathrm{mg} / \mathrm{kg}$, every $8 \mathrm{~h})$ [90].

\section{Combinations of GCs with other drugs}

Regarding the results of experimental and clinical studies, GCs may show some benefit in the treatment of MAS. However, due to the complex and multifactorial pathophysiology of the disease, other drugs (e.g. exogenous surfactant) should be included in the therapeutic scheme, too. In newborns with MAS, intravenous dexamethasone at a single dose of $0.5 \mathrm{mg} / \mathrm{kg}$ was administered within the first $5 \mathrm{~h}$ of life prior to a bronchoalveolar lavage using beractant $(5 \mathrm{mg} / \mathrm{ml})$ in a volume of $15 \mathrm{ml} / \mathrm{kg}$ in four aliquots [62]. The authors found that the surfactant lung lavage in combination with dexamethasone pretreatment may improve the status of the newborns with MAS more effectively than the surfactant lavage alone [62]. Similarly, in animal models of acute lung injury, the combination of dexamethasone with exogenous surfactant showed an additional improvement to the surfactant treatment alone $[13,26]$.

By utilization of their synergic or additive effects, GCs may be well combined also with other medicaments, e.g. with methylxanthine derivatives such as theophylline [32], with antioxidants such as $N$-acetylcysteine [33] or with $\beta_{2^{-}}$ agonists such as terbutaline [84]. In the experimental model of MAS, intratracheal budesonide followed by the intravenous administration of aminophylline improved the lung functions more effectively than aminophylline alone [53].

\section{Concluding remarks}

Despite the increasing number of trials with GCs in experimental models and newborns with MAS, their administration is still missing in the generally accepted therapeutic protocol of MAS. However, favourable results from the studies indicate that GCs may be beneficial, particularly in severe forms of MAS with apparent lung edema, pulmonary vasoconstriction and inflammation.

Summarizing all mentioned data, in the future, the research activities should be focused on an appropriate dosing, timing and ways of administration of GCs considering their individual properties and possible acute and long-term side effects. Since the causal treatment of MAS should consist of several agents, it is necessary to also verify the promising combinations of GCs with other drugs, particularly with exogenous surfactant, antiinflammatory drugs and pulmonary vasodilators.

Acknowledgement This work was supported by "Center of Excellence for Perinatology Research" Project No. 26220120016 cofinanced by EU sources and by Ministry of Education VEGA Project Nos. 1/0061/08, 1/0057/11 and 1/0030/11.

Conflicts of interest The authors have no financial relationship with the organization that sponsored the research.

Open Access This article is distributed under the terms of the Creative Commons Attribution Noncommercial License which permits any noncommercial use, distribution, and reproduction in any medium, provided the original author(s) and source are credited.

\section{References}

1. Anttila E, Peltoniemi O, Haumont D, Herting E, ter Horst H, Heinonen K, Kero P, Nykänen P, Oetomo SB, Hallman M (2005) Early neonatal dexamethasone treatment for prevention of bronchopulmonary dysplasia. Randomised trial and meta-analysis evaluating the duration of dexamethasone therapy. Eur J Pediatr 164:472-481

2. Bae CW, Takahashi A, Chida S, Sasaki M (1998) Morphology and function of pulmonary surfactant inhibited by meconium. Pediatr Res 44:187-191

3. Barnes PJ (1995) Inhaled glucocorticoids for asthma. N Engl J Med 332:868-875

4. Basu S, Kumar A, Bhatia BD, Satya K, Singh TB (2007) Role of steroids on the clinical course and outcome of meconium aspiration syndrome - a randomized controlled trial. J Trop Pediatr 53:331-337

5. Baud O (2004) Antenatal corticosteroid therapy: benefits and risks. Acta Paediatr Suppl 93:6-10 
6. Bryan SA, Leckie MJ, Hansel TT, Barnes PJ (2000) Novel therapy for asthma. Expert Opin Investig Drugs 9:25-42

7. Burgess AM, Hutchins GM (1996) Inflammation of the lungs, umbilical cord and placenta associated with meconium passage in utero. Review of 123 autopsied cases. Pathol Res Pract 192:11211128

8. Buttgereit F, Scheffold A (2002) Rapid glucocorticoid effects on immune cells. Steroids 67:529-534

9. Buttgereit F, Brand MD, Burmester GR (1999) Equivalent doses and relative drug potencies for non-genomic glucocorticoid effects: a novel glucocorticoid hierarchy. Biochem Pharmacol $58: 363-368$

10. Buttgereit F, Straub RH, Wehling M, Burmester GR (2004) Glucocorticoids in the treatment of rheumatic diseases: an update on the mechanisms of action. Arthritis Rheum 50:34083417

11. Castellheim A, Lindenskov PH, Pharo A, Aamodt G, Saugstad OD, Mollnes TE (2005) Meconium aspiration syndrome induces complement-associated systemic inflammatory response in newborn piglets. Scand J Immunol 61:217-225

12. Chen YZ, Qiu J (2001) Possible genomic consequence of nongenomic action of glucocorticoids in neural cells. News Physiol Sci 16:292-296

13. Chen CM, Fang CL, Chang CH (2001) Surfactant and corticosteroid effects on lung function in a rat model of acute lung injury. Crit Care Med 29:2169-2175

14. Chin R Jr, Eagerton DC, Salem M (1994) Corticosteroids. In: Chernow B (ed) The pharmacologic approach to the critically ill patient, 3rd edn. Williams \& Wilkins, Baltimore, pp 715-740, 1994

15. Cleary GM, Antunes MJ, Cieselka DA, Higgins ST, Spitzer AR, Chander A (1997) Exudative lung injury is associated with decreased levels of surfactant proteins in a rat model of meconium aspiration. Pediatrics 100:998-1003

16. Co E, Vidyasagar D (1990) Meconium aspiration syndrome. Compr Ther 16:34-39

17. Craig S, Lopez A, Hoskin D, Markham F (2005) Meconium inhibits phagocytosis and stimulates respiratory burst in alveolar macrophages. Pediatr Res 57:813-818

18. da Costa DE, Nair AK, Pai MG, Al Khusaiby SM (2001) Steroids in full term infants with respiratory failure and pulmonary hypertension due to meconium aspiration syndrome. Eur J Pediatr 160:150-153

19. Dargaville PA, Copnell B, Australian and New Zealand Neonatal Network (2006) The epidemiology of meconium aspiration syndrome: incidence, risk factors, therapies, and outcome. Pediatrics 117:1712-1721

20. de Beaufort AJ, Bakker AC, van Tol MJD, Poorthuis BJ, Schrama AJ, Berger HM (2003) Meconium is a source of pro-inflammatory substances and can induce cytokine production in cultured A549 epithelial cells. Pediatr Res 54:491-495

21. Dubois EFL (2005) Clinical potencies of glucocorticoids: what do we really measure? Curr Respir Med Rev 1:103-108

22. Fajardo C, Levin D, Garcia M, Abrams D, Adamson I (1998) Surfactant versus saline as a vehicle for corticosteroid delivery to the lungs of ventilated rabbits. Pediatr Res 43:542-547

23. Falkenstein E, Tillmann HC, Christ M, Feuring M, Wehling M (2000) Multiple actions of steroid hormones - a focus on rapid, nongenomic effects. Pharmacol Rev 52:513-556

24. Fernandes ABS, Zin WA, Rocco PRM (2005) Corticosteroids in acute respiratory distress syndrome. Braz J Med Biol Res 38:147159

25. Frantz ID, Wang NS, Thach BT (1975) Experimental meconium aspiration: effects of glucocorticoid treatment. J Pediatr 86:438441
26. Häfner D, Germann PG (1999) Dexamethasone enhances the activity of rSP-C surfactant but not of exosurf in a rat model of the acute lung injury. J Pharmacol Toxicol Methods 42:39-48

27. Hageman JR, Caplan MS (1995) An introduction to the structure and function of inflammatory mediators for clinicians. Clin Perinatol 22:251-261

28. Holopainen R, Soukka H, Halkola L, Kääpä P (1998) Meconium aspiration induces a concentration-dependent pulmonary hypertensive response in newborn piglets. Pediatr Pulmonol 25:107-113

29. Holopainen R, Aho H, Laine J, Peuravuori H, Soukka H, Kääpä $P$ (1999) Human meconium has high phospholipase A2 activity and induces cellular injury and apoptosis in piglet lungs. Pediatr Res 46:626-632

30. Holopainen R, Laine J, Halkola L, Aho H, Kääpä P (2001) Dexamethasone treatment attenuates pulmonary injury in piglet meconium aspiration. Pediatr Res 49:162-168

31. Hvizdos KM, Jarvis B (2000) Budesonide inhalation suspension: a review of its use in infants, children and adults with inflammatory respiratory disorders. Drugs 60:1141-1178

32. Ito K, Lim S, Caramori G, Cosio B, Chung KF, Adcock IM, Barnes PJ (2002) A molecular mechanism of action of theophylline: induction of histone deacetylase activity to decrease inflammatory gene expression. Proc Natl Acad Sci USA 99:8921-8926

33. Jansson AH, Eriksson C, Wang X (2005) Effects of budesonide and $\mathrm{N}$-acetylcysteine on acute lung hyperinflation, inflammation and injury in rats. Vascul Pharmacol 43:101-111

34. Jantz MA, Sahn AS (1999) Corticosteroids in acute respiratory failure. Am J Respir Crit Care Med 160:1079-1100

35. Kakinuma R, Shimizu H, Ogawa Y (2002) Effect of meconium on the rate of in vitro subtype conversion of swine pulmonary surfactant. Eur J Pediatr 161:31-36

36. Katzung BG (ed) (2007) Basic and clinical pharmacology, 10th edn. McGraw-Hill Medical, 1179 p. ISBN 978-007-126093-0

37. Khan AM, Shabarek FM, Kutchback JW, Lally KP (1999) Effects of dexamethasone on meconium aspiration syndrome in newborn piglets. Pediatr Res 46:179-183

38. Khan AM, Elidemir O, Epstein CE, Lally KP, Xue H, Blackburn M, Larsen GL, Colasurdo GN (2002) Meconium aspiration produces airway hyperresponsiveness and eosinophilic inflammation in a murine model. Am J Physiol Lung Cell Mol Physiol 283: L785-L790

39. Kirimi E, Tuncer O, Kösem M, Ceylan E, Tas A, Tasal I, Balahoroğlu R, Caksen H (2003) The effects of prednisolone and serum malondialdehyde levels in puppies with experimentally induced meconium aspiration syndrome. J Int Med Res 31:113122

40. Kopelman AE, Moise AA, Holbert D, Hegemier SE (1999) A single very early dexamethasone dose improves respiratory and cardiovascular adaptation in preterm infants. J Pediatr 135:345350

41. Kuo CY, Chen JY (1999) Effects of meconium aspiration on plasma endothelin-1 level and pulmonary hemodynamics in a piglet model. Biol Neonate 76:228-234

42. Kytola J, Kääpä P, Uotila P (2003) Meconium aspiration stimulates cyclooxygenase- 2 and nitric oxide synthase- 2 expression in rat lungs. Pediatr Res 53:731-736

43. Leckie MJ, Bryan SA, Hansel TT, Barnes PJ (2000) Novel therapy for COPD. Expert Opin Investig Drugs 9:3-23

44. Li YH, Yan ZQ, Brauner A, Tullus K (2001) Meconium induces expression of inducible NO synthase and activation of NF- $\mathrm{KB}$ in rat alveolar macrophages. Pediatr Res 49:820-825

45. Linder BL, Esteban NV, Yergey AL, Winterer JL, Loriaux DL, Cassorl F (1990) Cortisol production rate in childhood and adolescence. J Pediatr 117(6):892-896 
46. Lösel R, Wehling M (2003) Nongenomic actions of steroid hormones. Nat Rev Mol Cell Biol 4:46-56

47. Miller WL, Achermann JC, Flück CE (2008) The adrenal cortex and its disorders. In: Sperling MA (ed) Pediatric endocrinology, 3rd edn. Saunders Elsevier, Philadelphia, pp 444-511, 2008

48. Mokra D, Mokry J (2010) Meconium aspiration syndrome. From pathomechanisms to treatment. Nova, New York, p 130 p. ISBN 978-1-60876-944-5

49. Mokra D, Calkovska A, Tonhajzerova I, Petraskova M, Bulikova J, Redfors B, Javorka K (2007) Intratracheal budesonide improved the lung functions in meconium-instilled rabbits without side effects on cardiovascular functions. Eur Respir J 30(Suppl 51):396 p

50. Mokra D, Mokry J, Drgova A, Bulikova J, Petraskova M, Calkovska A (2007) Single-dose vs. two-dose dexamethasone effects on lung inflammation and airway reactivity in meconium-instilled rabbits. J Physiol Pharmacol 58(Suppl 5):379-387

51. Mokra D, Mokry J, Drgova A, Petraskova M, Bulikova J, Calkovska A (2007) Intratracheally administered corticosteroids improved the lung functions in meconium-instilled rabbits. J Physiol Pharmacol 58(Suppl 5):389-398

52. Mokra D, Calkovska A, Tonhajzerova I, Petraskova M, Bulikova J, Redfors B (2008) Dexamethasone treatment improved lung functions in meconium-instilled rabbits, but influenced cardiovascular variables. Bratisl Med J 109:95-101

53. Mokra D, Drgova A, Mokry J, Bulikova J, Pullmann R, Durdik P, Petraskova M, Calkovska A (2008) Combination of budesonide and aminophylline diminished acute lung injury in animal model of meconium aspiration syndrome. J Physiol Pharmacol 59(Suppl 6):461-471

54. Mokra D, Tonhajzerova I, Mokry J, Drgova A, Petraskova M, Calkovska A, Javorka K (2008) Rapid cardiovascular effects of dexamethasone in rabbits with meconium-induced acute lung injury. Can J Physiol Pharmacol 86:804-814

55. Mokry J, Mokra D, Antosova M, Bulikova J, Calkovska A, Nosalova G (2006) Dexamethasone alleviates meconium-induced airway hyperresponsiveness and lung inflammation in rabbits. Pediatr Pulmonol 41:55-60

56. Moses D, Holm BA, Spitale P, Liu M, Enhorning G (1991) Inhibition of pulmonary surfactant function by meconium. Am J Obstet Gynecol 164:477-481

57. Newton R (2000) Molecular mechanisms of glucocorticoid action: what is important? Thorax 55:603-613

58. Nimmo AJ, Carstairs JR, Patole SK, Whitehall J, Davidson K, Vink R (2002) Intratracheal administration of glucocorticoids using surfactant as a vehicle. Clin Exp Pharmacol Physiol 29:661-665

59. Pan NY, Hui WS, Tipoe GL, Taylor GW, Leung RY, Lam WK, Tsang KW, Mak JC (2006) Inhibition of pyocyanin-potentiated IL-8 release by steroids in bronchial epithelial cells. Respir Med 100:1614-1622

60. Purdy IB, Wiley DJ (2004) Perinatal corticosteroids: a review of research. Part I: antenatal administration. Neonatal Netw 23:15-30

61. Rizzo MC, Solé D (2006) Inhaled corticosteroids in the treatment of respiratory allergy: safety vs. efficacy. J Pediatr (Rio J) 82: S198-S205

62. Salvia-Roiges MD, Carbonell-Estrany X, Figueras-Aloy J, RodríguezMiguélez JM (2004) Efficacy of three treatment schedules in severe meconium aspiration syndrome. Acta Paediatr 93:60-65

63. Schäcke H, Döcke W-D, Asadullah K (2002) Mechanisms involved in the side effects of glucocorticoids. Pharmacol Ther 96:23-43

64. Schmid D, Burmester GR, Tripmacher R, Kuhnke A, Buttgereit F (2000) Bioenergetics of human peripheral blood mononuclear cell metabolism in quiescent, activated, and glucocorticoid-treated states. Biosci Rep 20:289-302

65. Schrama AJ, de Beaufort AJ, Sukul YR, Jansen SM, Poorthuis BJ, Berger HM (2001) Phospholipase A2 is present in meconium and inhibits the activity of pulmonary surfactant: an in vitro study. Acta Paediatr 90:412-416

66. Soukka H, Halkola L, Aho H, Rautanen M, Kero P, Kääpä $P$ (1997) Methylprednisolone attenuates the pulmonary hypertensive response in porcine meconium aspiration. Pediatr Res $42: 145-150$

67. Soukka H, Jalonen J, Kero P, Kääpä P (1998) Endothelin-1, atrial natriuretic peptide and pathophysiology of pulmonary hypertension in porcine meconium aspiration. Acta Paediatr $87: 424-428$

68. Soukka H, Viinika L, Kääpä P (1998) Involvement of thromboxane $\mathrm{A}_{2}$ and prostacyclin in the early pulmonary hypertension after porcine meconium aspiration. Pediatr Res 44:838-842

69. Soukka HR, Ahotupa M, Ruutu M, Kääpä P (2002) Meconium stimulates neutrophil oxidative burst. Am J Perinatol 19:279-284

70. Stahn C, Löweneberg M, Hommes DW, Buttgereit F (2007) Molecular mechanisms of glucocorticoid action and selective glucocorticoid receptor agonists. Mol Cell Endocrinol 275:71-78

71. Stellato C (2004) Post-transcriptional and nongenomic effects of glucocorticoids. Proc Am Thorac Soc 1:255-263

72. Suchomski SJ, Cummings JJ (2002) A randomized trial of inhaled versus intravenous steroids in ventilator-dependent preterm infants. J Perinatol 22:196-203

73. Sun HW, Miao CY, Liu L, Zhou J, Su DF, Wang YX, Jiang CL (2006) Rapid inhibitory effect of glucocorticoids on airway smooth muscle contractions in guinea pigs. Steroids 71:154-159

74. Thomson/Micromedex (2007) Drug information for the health care professional, vol 1. Greenwood Village, CO, p 898

75. Thung SF, Norwitz ER (2009) Endocrine diseases in pregnancy. In: Strauss JF, Barbieri RL (eds) Yen and Jaffe's reproductive endocrinology: physiology, pathophysiology and clinical management, 6th edn. Saunders Elsevier, Philadelphia, pp 615-658, 2009

76. Tølløfsrud PA, Lindenskov PH, Drevon CA, Speer CP, Seidenspinner S, Saugstad OD (2003) Comparison of pulmonary and inflammatory effects of lipid- and water-soluble components in meconium in newborn piglets. Biol Neonate 84:330-337

77. Tripathi S, Saili A (2007) The effect of steroids on the clinical course and outcome of neonates with meconium aspiration syndrome. J Trop Pediatr 53:8-12

78. Tripathi S, Saili A, Dutta R (2007) Inflammatory markers in meconium induced lung injury in neonates and effect of steroids on their levels: a randomized controlled trial. Indian $\mathrm{J}$ Med Microbiol 25:103-107

79. Urbach V, Walsh DE, Mainprice B, Bousquet J, Harvey BJ (2002) Rapid non-genomic inhibition of ATP-induced $\mathrm{Cl}^{-}$secretion by dexamethasone in human bronchial epithelium. J Physiol 545:869-878

80. Vázquez Nava F, Salas Ramírez E, Sánchez Núncio HR, Saldivar González AH, Beltrán Saldaňa J, Cadena Mata D, Pérez Rodríguez P, Pérez Martin J, Almeida VM, Guidos Fogelbach G (2006) Meconium aspiration syndrome, parental atopy and asthma symptoms in children under two years old. Rev Alerg Méx 53:130-135

81. Verriére VA, Hynes D, Faherty S, Devaney J, Bousquet J, Harvey BJ, Urbach V (2005) Rapid effects of dexamethasone on intracellular $\mathrm{pH}$ and $\mathrm{Na}^{+} / \mathrm{H}^{+}$exchanger activity in human bronchial epithelial cells. J Biol Chem 280:35807-35814

82. Vidyasagar D, Zagariya A (2008) Studies of meconium-induced lung injury: inflammatory cytokine expression and apoptosis. $\mathrm{J}$ Perinatol 28:S102-S107

83. Wang JY, Yeh TF, Lin YJ, Chen WY, Lin CH (1997) Early postnatal dexamethasone therapy may lessen lung inflammation in premature infants with respiratory distress syndrome on mechanical ventilation. Pediatr Pulmonol 23:193-197

84. Wang J, Zhang L, Walther SM (2004) Administration of aerosolized terbutaline and budesonide reduces chlorine gasinduced acute lung injury. J Trauma 56:850-862 
85. Wehling M (1997) Specific nongenomic actions of steroid hormones. Ann Rev Physiol 59:365-393

86. Wu JM, Yeh TF, Wang JY, Wang JN, Lin YJ, Hsieh WS, Lin CH (1999) The role of pulmonary inflammation in the development of pulmonary hypertension in newborn with meconium aspiration syndrome (MAS). Pediatr Pulmonol 18(Suppl):205-208

87. Yamada T, Minakami H, Matsubara S, Yatsuda T, Kohmura Y, Sato I (2000) Meconium-stained amniotic fluid exhibits chemotactic activity for polymorphonuclear leukocytes in vitro. J Reprod Immunol 46:21-30

88. Yeh TF, Srinivasan G, Harris V, Pildes RS (1977) Hydrocortisone therapy in meconium aspiration syndrome: a controlled study. J Pediatr 90:140-143
89. Yeh TF, Lin YJ, Huang CC, Chen YJ, Lin CH, Lin HC, Hsieh WS, Lien YJ (1998) Early dexamethasone therapy in preterm infants: a follow-up study. Pediatrics 101:E7

90. Yeh TF, Lin HC, Chang CH, Wu TS, Su BH, Li TC, Pyati S, Tsai CH (2008) Early intratracheal instillation of budesonide using surfactant as a vehicle to prevent chronic lung disease in preterm infants: a pilot study. Pediatrics 121:e1310-e1318

91. Zhou J, Kang Z-M, Xie Q-M, Liu C, Lou S-J, Chen Y-Z, Jiang CL (2003) Rapid nongenomic effects of glucocorticoids on allergic asthma reaction in the guinea pig. J Endocrinol 177:R1R4

92. Zoban P, Cerny M (2003) Immature lung and acute lung injury. Physiol Res 52:507-516 